\title{
Vezljivost treh glagolov mišljenja v zgodovini slovenskega knjižnega jezika (s poudarkom na vezavi)
}

\author{
Robert Grošelj
}

\begin{abstract}
Razprava obravnava razvoj vezljivosti mišljenjskih glagolov misliti, mneti, meniti v zgodovini slovenskega knjižnega jezika (s poudarkom na vezavi). Opredeljeni so pomeni glagolov, po pomenih so vzpostavljeni pomenski in vezavnostni vzorci, določena je njihova stabilnost, razvojne značilnosti in medsebojna konkurenčna razmerja. Na koncu razprave so primerjane vezljivostne značilnosti med glagoli mišljenja.
\end{abstract}

Ključne besede: zgodovina slovenščine, razvoj vezljivosti, vezava, glagoli mišljenja

The valency of three verbs of thinking in the history of standard Slovenian (with an emphasis on government)

This article examines the development of valency for the verbs of thinking misliti 'to think', mneti 'to believe', and meniti 'to believe' in the history of Slovenian (with an emphasis on government). It defines the meanings of the verbs, presents their semantic and government patterns by meaning, and defines their stability, developmental characteristics, and competition with one another. The article concludes with a comparison of the valency characteristics among the verbs of thinking.

Key words: history of Slovenian, development of valency, government, verbs of thinking

\section{Uvod}

V razpravi je predstavljen razvoj vezljivosti mišljenjskih glagolov misliti, mneti, meniti $\mathrm{v}$ zgodovini slovenskega knjižnega jezika (s poudarkom na vezavi). Na podlagi slovenskih slovarskih del je opredeljeno pomenje glagolov mišljenja, s pomočjo korpusa, ki ga sestavljajo besedilnih zgledi iz celotnega knjižnojezikovnega razvoja slovenskega jezika, pa so določene vezljivostne značilnosti glagolov, kot se kažejo skozi zgodovino jezika. Po posameznih pomenih glagolov so vzpostavljeni najprej pomenski, nato vezavnostni vzorci, določena je njihova stabilnost, razvojne značilnosti in medsebojna konkurenčna razmerja. $\mathrm{Na}$ koncu razprave so primerjane vezljivostne značilnosti glagolov mišljenja, s čimer se lahko izpostavijo tudi konkurenčna razmerja med glagoli v opredeljenih pomenih. 
Namena večstopenjske diahrone vezljivostne analize pomensko sorodnih glagolov sta dva: (1) prikazati večplastnost vezljivostnih zmožnosti mišljenjskih glagolov in razmerij med njimi skozi zgodovino slovenskega jezika; (2) dokazati, da se s spreminjanjem pomena glagolov spreminjata tudi njihova vezljivost in vezava (za slednje prim. Žele 2003). ${ }^{1}$

\subsection{Gradivo in korpus}

0.1.1 Gradivo raziskave predstavljajo slovenski glagoli mísliti, mnéti, méniti (tudi meníti). ${ }^{2}$ Glagoli pomensko spadajo med mišljenjske, kot takšne pa jih lahko opredelimo tudi etimološko (prim. psl. *mysliti, *mıněti, *měniti; gl. razdelek 1).

0.1.2 Korpus za vezljivostno analizo slovenskih glagolov mišljenja sestavljajo izpisi celotnih besedilnih zgledov iz slovarskih in neslovarskih del, ki pokrivajo ves knjižnojezikovni razvoj slovenskega jezika (od 10. do 21. stoletja; obsežno gradivo se pojavi šele z nastopom knjižnega obdobja $\mathrm{v}$ drugi polovici 16. stoletja).

Za predknjižno obdobje je bilo v raziskavi upoštevano gradivo Brižinskih spomenikov (10.-11. stoletje; BS) in besedil predknjižnega izročila (od 14. stoletja do leta 1550; Mikhailov 1998). Za 16. stoletje so bila pregledana tale dela: P. Trubar (T) $-\mathrm{Ca}$ techismus in Abecedarium iz leta 1550 (TC 1550, TA), Articuli oli deili te prave, stare vere kersčanske iz leta 1562 (TAr), Cerkovna ordninga iz leta 1564 (TO) in Ta celi catehismus, eni psalmi inu tih vegših godii stare inu nove kersčanske peisni iz leta 1574 (TC 1574); S. Krelj (K) - Otrozhia Biblia iz leta 1566 (KB); J. Dalmatin (D) - Biblia iz leta 1584 (DB). Za 17. stoletje je bil upoštevan Slovar jezika Janeza Svetokriškega (2006; SJJSv), za 18. stoletje pa Japljev prevod Svetega pisma (1784-1802; Jap). Za 19. stoletje so bili pregledani Slovar Prešernovega pesniškega jezika (1977; Prě̌.), Wolfov prevod Svetega pisma (1856-1859; W) in Pleteršnikov slovar (1894-1895; Plet.). Za 20. stoletje sta bila upoštevana Slovar slovenskega knjižnega jezika (19701991, 1998; SSKJ) in Vezljivostni slovar slovenskih glagolov A. Žele (2008; VSSG). ${ }^{3}$

\section{$0.2 \quad$ Metode}

0.2.1 Pomenska analiza glagolov mišljenja izhaja iz pomenskih razlag $v$ analiziranih slovarskih virih. Pomenske razlage se je skušalo uravnotežiti s preveritvijo besedilnih zgledov, poskus dopolnitve pa je slonel na urejevalnem, sintagmatskem načelu slovarskega pomena: slovarski pomen izkazuje podredno razmerje pomenskih sestavin s

1 Razprava je predelano poglavje avtorjeve disertacije Vezava glagolov umevanja $v$ slovanskih jezikih (mentorici red. prof. dr. Alenka Šivic-Dular, izr. prof. dr. Andreja Žele), obranjene februarja 2010 na Oddelku za slavistiko Filozofske fakultete Univerze v Ljubljani.

2 Iz analize so izključene tvorjenke z omenjenimi glagoli v skladenjski podstavi (po teoriji slovenskega skladenjskega besedotvorja, prim. Vidovič-Muha 1988); raziskava njihovih pomenskih in vezljivostnih sprememb glede na netvorjenke si zasluži ločeno obravnavo (upoštevati bi bilo treba predvsem sestavljenke in tvorjenke s povratnoosebnim zaimkom kot prostim morfemom).

3 Izpisani zgledi z izpričanimi vezljivostnimi (pomenskimi in vezavnostnimi) značilnostmi glagolov so bili na podlagi uveljavljenih zapisov (prim. predvsem SPP) oblikovani v pomenske in vezavnostne vzorce, primerne za vezljivostno analizo. 
skladenjsko vodilno uvrščevalno pomensko sestavino (UPS) in skladenjsko odvisnimi razločevalnimi pomenskimi sestavinami (RPS; Vidovič-Muha 2000: 53).

$\mathrm{Na}$ ta način so bili vzpostavljeni tudi t. i. primerljivi pomeni, tj. pomeni $\mathrm{z}$ enako UPS in čim več prekrivnimi RPS, ki omogočajo primerjavo vezljivostnih možnosti med glagoli.

Sistematizacija slovarskih virov in zgledov, ki temelji na zgodovinskorazvojnem urejevalnem načelu, omogoča opredelitev pomenov z vidika časovne ustaljenosti (v katerem obdobju se pomen pojavlja). Podatki o časovni ustaljenosti pomenov so sicer podrejeni njihovi relativni razvrstitvi, ki temelji na kriteriju pogostnosti.

0.2.2 Vezljivostna analiza glagolov mišljenja temelji na sodobnih obravnavah glagolske vezljivosti (prim. Karolak 1984, VV 1987, Žele 2001). Vezljivost je zmožnost določene besede (t. i. nosilca vezljivosti), ${ }^{4}$ da veže nase napovedljivo število vezljivostnih položajev, je torej napovedljivost/obveznost skladenjskih mest (nasproti družljivosti, ki označuje prosta mesta). Obvezna skladenjska mesta, ki so napovedljiva iz pomenske usmerjenosti glagola ( $\mathrm{z}$ udeleženskimi vlogami), so zasedena $\mathrm{s}$ t. i. določili v določeni slovnični obliki (strukturnoskladenjska vezljivost; Žele 2001: 13). ${ }^{5}$

Pomenska usmerjenost ali pomenskoskladenjska vezljivost je lastnost nosilca vezljivosti, da s svojim pomenom jezikovno odraža določeno zunajjezikovno mikrosituacijo; pomenske entitete, ki ustrezajo predmetnim ali abstraktnim sestavinam zunajjezikovne mikrosituacije, predstavljajo udeleženci. Njihovo vsebinsko opredelitev pokrivajo udeleženske vloge; v sodobnih vezljivostnih razpravah se pogosto stremi k njihovi tipizaciji (npr. SČ 1998: 38-41; tudi Orešnik 1992).

Na podlagi pomenov in besedilnih zgledov so bile določene tudi pomenskoskladenjske značilnosti glagolov mišljenja v slovenskem jeziku. Osrednjo vlogo med njimi imajo udeleženci, ki jih predvideva usmerjenost glagola. Na podlagi glagolskega pomena, pomenskih in skladenjsko-oblikovnih lastnosti udeležencev so se oblikovale njihove udeleženske vloge. Kompleksno pomensko (vezljivostno) razmerje med udeleženci, ki ga usmerja nosilec vezljivosti (usmerjenosti), ponazarjajo pomenski (vezljivostni) vzorci, npr. nosilec mišljenja - vsebina (brez upoštevanja predvidljivega nosilca, npr. misliti-kaj). ${ }^{6}$

Pomenska usmerjenost se izrazno uresničuje v strukturnoskladenjski vezljivosti, ki je v raziskavi poimenovana vezava (po Dular 1982). Udeleženci pomenske usmerjenosti glagola so skladenjsko ali - bolje - besedilno realizirani kot določila $^{7} \mathrm{v}$ določeni slovnični obliki (oblikoslovne, oblikoskladenjske kategorije

4 Najbolj tipični nosilci vezljivosti so glagoli, pridevniki (označujejo različna stanjska lastnostna razmerja), poleg njih pa še izglagolski in izpridevniški samostalniki (Žele 2001: 15).

5 Nepolnopomenski glagoli oz. glagoli v pomožniški vlogi kot slovničnofunkcijska jedra povedi lahko v okviru strukturnoskladenjske vezljivosti uvajajo samó neudeležensko povedkovodoločilno vezljivost (Žele 2001: 13).

6 Pri opisni predstavitvi pomenskega vzorca levi udeleženec ni upoštevan, in sicer zaradi njegove predvidljivosti.

7 Določila so lahko na levi ali desni strani jedra (nosilca vezljivosti). T. i. levi vezljivosti pripadajo določila v skladenjski funkciji osebka (v nekaterih vezljivostnih pristopih tudi logičnega osebka), medtem ko ostala določila pripadajo t. i. desni vezljivosti. 
tipa sklon, nedoločnik, odvisnik itn.). Vezava je vpliv skladenjsko odločilnih slovarskih lastnosti besedne podstave nosilca vezljivosti na izbiro kategorialnih (neslovarskih) lastnosti določila (slovnična oblika) oz. predvidljivosti teh lastnosti na podlagi slovarskih lastnosti nosilca vezljivosti (prir. po Dular 1982: 78).

$\mathrm{Na}$ osnovi ugotovljenih pomenskih (vezljivostnih) razmerij, udeležencev in besedilnih zgledov so se razkrile strukturnoskladenjske značilnosti slovenskih glagolov mišljenja. Iz besedilnih zgledov so se izpostavila določila oz. določilne možnosti, vzporednost pomenskega in strukturnega vezljivostnega razmerja v okvirih posameznih pomenov pa je prikazana s pomočjo vezavnostnih vzorcev, ki predstavljajo formulaični prikaz vseh določilnih realizacij pomena glagolskega leksema, npr. Snom - VF - SENT. V okvirih posameznih pomenov je bil določen časovni lok pojavljanja vzorca, njegova stabilnost oz. nestabilnost, vzorci pa so bili glede na kriterij stabilnosti primerjani med seboj. ${ }^{8}$

V slovenskem jeziku so bile nato primerjane vezljivostne značilnosti po posameznih pomenih; tako je postala jasna razvojna stabilnost pomenskih in vezavnostnih vzorcev, hkrati pa so se razkrila konkurenčna razmerja med glagoli samimi (po pomenih in verjetno tudi absolutno).

\section{$1 \quad$ Pomenje glagolov mišljenja v slovenskem jeziku}

\subsection{Pomenje glagola MISLITI}

Sln. mísliti, mîslim nedov. izkazuje tele pomene: (1) 'misliti, razmišljati', (2) 'nameravati' in (3) 'misliti, snovati v škodo/korist' (prim. Plet. I: 580; SSKJ: 557). ${ }^{9}$

8 Kot stabilen vzorec se obravnava gradivsko dobro izkazan vzorec, ki se pojavlja v načeloma daljšem časovnem obdobju (za krajše obdobje mora zadostiti pogoju zelo dobre gradivske izpričanosti). Nestabilen vzorec je gradivsko šibko izkazan vzorec, ki se pojavlja v krajšem časovnem obdobju; kot nestabilni se obravnavajo tudi vzorci, ki se pojavljajo v daljših obdobjih, a so izkazani s sporadičnimi, osamljenimi zgledi. - Ob sorazmerno fragmentarnem korpusu je treba računati z neizkazovanjem vezljivostnih možnosti (tj. pomenskih in vezavnostnih vzorcev) v posameznih obdobjih. Tovrstne »vezljivostne praznine« se zapolnijo, če je vezljivostna možnost izkazana v prehodnih in kasnejših obdobjih ali če jo potrjuje sekundarna literatura. V tabelarnih prikazih so zapolnjene »vezljivostne praznine« označene z znakom $\mathbf{m}$.

9 Etimološki komentar: sln. mîsel, gen. mîsli (15. stoletje) ž., mísliti (10. stoletje) k psl. *mÿslb, rod. *mÿsli in izsam. *mysliti, vzporedno *myslěti (A. Vaillant domneva, da je nedol. osnova na -ěe- nadomestila starejšo na -i-; ESSJ 21: 43-44, 45-46); ide. *mū $d^{h} s l(i)$ - ali *mū $d^{h} t l(i)$ - iz ide. baze $m e u d^{h}$ - 'paziti na, misliti na' (Snoj 2003: 404; ESJS: 508-509).

Pomenski komentar: Plet. in SSKJ navajata tele pomene: (a) 'misliti, razmišljati; meniti; nameravati' ('denken, sinnen; denken, meinen; beabsichtigen'; Plet. I: 580); (b) 1. biti dejaven v zavesti; $\mathbf{2}$. imeti povedano glede na svoje védenje, poznavanje za resnično; 3. imeti pozitiven, negativen odnos do koga/česa; 4. izraža a) namero, namen; b) opravičilo, pojasnilo; izraža možnost uresničitve česa; 5. v zvezi z reči uvaja a) natančnejšo določitev, dopolnitev povedanega; b) povzetek bistvene vsebine povedanega; 6. izraža točno, konkretno določitev povedanega; 7. v medmetni rabi, navadno v zvezi z ali, kaj izraža a) začudenje, nejevoljo; b) podkrepitev trditve (SSKJ: 557). Pomeni (b) 1-3 in 5-7 
Pomen (1) je pri glagolu gradivsko izpričan v obdobju od 10. do 21. stoletja, pomen (2) od 16. do 21. stoletja, medtem ko besedilni zgledi izkazujejo pomen (3) le v času od 16. do 19. stoletja.

\subsection{Pomenje glagola MNETI}

Sln. mnéti, mním nedov. pomeni (1) 'meniti' (prim. Plet. I: 587). M. Merše (1995: 264-264) opozarja, da je nihanje med meniti in mneti zaznamovalo Trubarjev jezik, dvojnost pa je bila razrešena v korist meniti - verjetno v 16. stoletju, iz katerega so osamljeni gradivski zgledi. ${ }^{10}$

\subsection{Pomenje glagola MENITI}

Sln. méniti in meníti, ménim nedov. izkazuje pomene (1) 'meniti, misliti, imeti za', (2) 'nameravati' in (3) 'reči, dejati' (prim. Plet. I: 566; SSKJ: 540). ${ }^{11}$

Pomena (1) in (2) sta pri glagolu gradivsko izpričana v obdobju od 16. do 21. stoletja, pomen (3) pa z redkimi besedilnimi zgledi le v 20. stoletju.

\section{$2 \quad$ Vezljivost glagolov mišljenja v slovenskem jeziku}

Glagole mišljenja v okviru leve vezljivosti zaznamuje Snom z oznako človeško, saj izkazujejo pomene, ki so lastni človeški duševnosti in obnašanju.

\subsection{Vezljivost glagola MISLITI}

2.1.1 Pri pomenu (1) 'misliti, razmišljati' so izpričane tele desne določilne moŽnosti:

ustrezajo zgornjemu (1), pomen 4 ustreza zgornjemu (2) ; preureditev pomenov (a) je razvidna. Zgornji pomen (3) ni zabeležen v nobenem izmed slovarjev, izhaja torej iz stanja v besedilih.

${ }^{10}$ Etimološki komentar: sln. mnéti, mním (nedov., 16. stoletje, pri starejših avtorjih) k psl. *mbnếti, sed. *mbníšb (nedol. *mbniti naj bi imel -i- iz sed.); ide. koren *men- 'misliti, premišljevati' (ESSJ 21: 115; Snoj 2003: 543). - V svojem gradivu glagola po 16. stoletju nisem zasledil (M. Pleteršnik sicer navaja možnost mni se mi 'zdi se mi' iz Ljubljanskega zvona, ki pa zaradi povratnoosebnega se ni upoštevana).

${ }^{11}$ Etimološki komentar: sln. menīti, ménim (nedov., 16. stoletje) k psl. *měnïti, sed. *mĕnišb; domneva se izpeljava iz nepotrjenega psl. *měnž; ide. *meino- (ali *moino-) 'mnenje, namen' (Snoj 2003: 392-393; ESJS: 467-468). - Pomenski komentar: Plet. in SSKJ navajata pomene: (a) 'meniti, misliti, imeti za' ('meinen, glauben, dafürhalten'; Plet. I: 566); (b) 1. knjiž., z odvisnim stavkom imeti povedano glede na svoje védenje, poznavanje za resnično; $\mathbf{2}$. knjiž., z nedoločnikom imeti namen, nameravati; $\mathbf{3}$. knjiž., izraža točno, konkretno določitev predmeta; misliti; 4. knjiž., v medmetni rabi, v zvezi z ali, kaj izraža začudenje, nejevoljo; misliti; 5. knjiž., reči, dejati (SSKJ: 540). Pomeni (b) 1, 3-4 ustrezajo zgornjemu (1), pomen 3 ustreza zgornjemu (2), pomen 5 pa zgornjemu (3); preureditev pomenov (a) je razvidna. 
- Desne določilne možnosti sln. misliti v pomenu (1)

\begin{tabular}{l|l|l|l|l|l|l|c|}
\hline & $\begin{array}{l}\text { Predknj. } \\
\text { obdobje }\end{array}$ & 16. st. & 17. st. & 18. st. & 19. st. & 20. st. \\
\hline Brez določila & & $\square$ & $\square$ & $\square$ & $\square$ & $\square$ \\
\hline Sak & & $\square$ & $\square$ & $\square$ & $\square$ & $\square$ \\
\hline naSak & & $\square$ & $\square$ & $\square$ & $\square$ & $\square$ \\
\hline vSak & $\square$ & $\square$ & & & $\square$ & \\
\hline kSdat & & & & & & $\square$ \\
\hline oSlok & & $\square$ & $\square$ & $\square$ & $\square$ & $\square$ \\
\hline poSlok & & & & & $\square$ & \\
\hline INF & & $\square$ & $\square$ & $\square$ & $\square$ & $\square$ \\
\hline SENT & $\square$ & $\square$ & $\square$ & $\square$ & $\square$ \\
\hline PG & & & $\square$ & $\square$ & \\
\hline Sak* - odSgen & & & & & $\square$ & $\square$ \\
\hline Sak* - oSlok & & & & & & $\square$ \\
\hline naSak - SENT & & $\square$ & & & & $\square$ \\
\hline odSgen - SENT & & $\square$ & $\square$ & $\square$ & $\square$ & \\
\hline oSlok - SENT & & & & & & $\square$ \\
\hline ADV & & $\square$ & $\square$ & $\square$ & $\square$ & $\square$ \\
\hline
\end{tabular}

Legenda:

$\square \quad$ gradivsko izkazana določilna možnost

- drugače izkazana oz. domnevana določilna možnost (prim. op. 8)

(A) Pri pomenu (1) je vzpostavljen pomenski vzorec nosilec mišljenja - vsebina. $\mathrm{Na}$ podlagi gradiva sklepam, da so stabilni vezavnostni vzorci tile: Snom - VF - Sak, Snom - VF - naSak in Snom - VF - SENT (domnevam, da je stilistično zaznamovana možnost s PG prav tako stabilna); stabilno (od 16. stoletja do danes) pa se je verjetno pojavljal tudi vzorec Snom - VF - ADV, s t. i. nadomestnim določilom ADV v vlogi vsebinskega udeleženca (več o določilu ADV, tudi s primeri, $\mathrm{v}$ razdelku 2.4.1).

Desno določilo SENT pokriva vlogo pravega vsebinskega udeleženca propozicijskega tipa, ki najbolje razkriva kompleksno vsebino mišljenjske dejavnosti. ${ }^{12}$ Nekoliko redkejše je določilo Sak v vlogi nepropozicijskega vsebinskega udeleženca (diktalnega tipa - kaj kdo misli); ${ }^{13}$ na njegovem mestu se večkrat pojavlja zaimenska oblika ali samostalnik kategorialnega, ekstenzivnega pomena (npr. reč, stvar), ki nadomešča kompleksnejšo vsebino, tj. SENT (prim. Dular 1982: 182). Stabilno je tudi določilo naSak z vlogo razmernega vsebinskega udeleženca (nanj se mišljenje vsebinsko nanaša), kaže pa na (izhodiščni) pomenski odtenek smerno-

${ }^{12}$ SENT ima lahko v glavnem stavku tudi navezovalni element (soodnosni izraz) tipa naSak, Sak, vSak (slednji v Wolfovem prevodu Svetega pisma) ter ADV (tako).

${ }^{13}$ Sak velja za najbolj tipično vezavno obliko in s svojimi oblikoslovnimi merili tudi za dovolj splošno, da ima lahko status sistemsko nezaznamovanega izraznega sredstva; posledica tega je tudi usmeritev slovenščine v tožilniško (ali t. i. analitično) vezljivost (Dular 1982: 162; Žele 2001: 78-79). 
sti, namere (Kopečný 1973: 117-118). PG se v vlogi vsebinskega udeleženca verjetno pojavlja prek »notranjega« govora (prim. 'misliti si'); ta stilistično zaznamovana besedilna določilna možnost je pretvorljiva v SENT (tudi zamenljiva je z njim).

Primeri: Snom - VF - Sak (16. st.: Sakaj GOSPVD eno rejzh mifli, inu bo tudi fturil, kar je on govoril supèr te, kateri v'Babeli prebivajo. Jer 51,12 DB; 18. st.: Nesaftópèn prasne rezhy mifli: nefpametèn, inu smóten pak mifli norfke rezhy. Sir 16,23 Jap; 20. st.: Očeta mislim, ne tebe. SSKJ). Snom - VF - naSak (16. st.: Ieft miflim na te ftare dny, pèrvih lejt. Ps 77,6 DB; 19. st.: Ker ne mislijo na smert, in njih nadloge (dolgo) ne terpé. Ps 72,4 W; 20. st.: Mislil je na bolečine. VSSG); Snom - VF - SENT (16. st.: Vy fte poprej sdaunaj po Davidu miflili, de bi on bil Krajl zhes vas: [...] 2 Sam 3,17 DB; 17. st.: [...] na letu nemislio, de bi fe sgreuali, spokorili, inu pobulshali [...] SJJSv (navezovalni naSak); 19. st.: [...] on le v to misli, kako bi podobne podobe napravil[...] Sir 38,28 W (navezovalni vSak); Takó mislite tudi vi, de ste namreč grehu odmerli, živite pa Bogu v Kristusu Jezusu, Gospodu našim. Rim 6,11 W (navezovalni tako); tudi brezvezniško: 16. st.: De ty ludy mislio inu menio, ta človik bo pravičin inu izvelyčan za volo suih lastnih dell inu zasluži tu odpusčane tih grehov za volo suiga lastniga zaslužena, [...] TO (III, 249); Snom - VF - PG (16. st.: Sakaj on je taku miflil: Lahkaj bi on tudi kej mogèl vmréti, kakòr njegovi bratje. $1 \mathrm{Mz} 38,11 \mathrm{DB}$; 19. st.: In je mislil sam per sebi, rekoč: Kaj bom storil, ker nimam, kamor bi svoje perdelke spravil? Lk 12,17 W). ${ }^{14}$

Kot nestabilni (ali manj stabilni) vezavnostni vzorci se kažejo Snom - VF - vSak // kSdat // poSlok; vzorci so redki in vezani na posamezna obdobja: vSak na 19. stoletje, kSdat na 10. in 16. stoletje, poSlok pa se pojavlja v 16. in 19. stoletju. Zdi se, da je nestabilen tudi vzorec Snom - VF - oSlok, potrjen samo v 20. stoletju. Izjemno vezljivostno možnost bi lahko predstavljal tudi Snom - VF - INF (19. stoletje).

Desna določila vSak, kSdat in poSlok pokrivajo vlogo razmernega vsebinskega udeleženca in kažejo na specifične izhodiščne pomene; njihova osamljenost in ujemanje s tujejezičnimi predlogami pa opozarjata na morebitno kalkiranost. ${ }^{15} \mathrm{~V}$ tej udeleženski vlogi je, presenetljivo, redko določilo oSlok; domnevam, da je pogostejše v kompleksnih vezavnostnih vzorcih, kjer nastopa kot del desne določilne možnosti (več o oSlok v razdelku 2.1.1(C)).

${ }^{14}$ V zvezi z določilom PG je treba omeniti dva pojava: (a) v besedilih 16. stoletja PG v glavnem stavku pogosto spremlja navezovalni prislov taku (prim. zgoraj); (b) v Jap in W PG pogosto uvaja deležnik glagola rekanja (18. st.: Ony fo pak famy pèr fèbi miflili rekózh: De my nifmo kruhe vsęli. Mt 16,7 Jap; 19. st.: Ko so pa kmetje tega zagledali, so mislili sami per sebi, rekoč: Ta je dedič, umorimo ga, de bo dédišina naša. Lk 20,14 W)

${ }^{15}$ Določilo vSak (s smernostnim pomenom) bi lahko nastalo s kontaminacijo - pod vplivom določilne možnosti pomensko sorodnega glagola, prim. verjeti v koga. Ob določilu kSdat v DB, prav tako z izhodiščno smernostnim pomenom (Kopečný 1973: 101), se ponuja razlaga s kalkiranostjo - o njej pričata redkost zgleda in ujemanje DB z Lutrovo predlogo (prim. $z u$ z daj.); v primeru kSdat v BS pa bi lahko šlo za kontaminacijo (prim. stcsl. glagole verovanja, upanja; SJS II: 87). Določilo poSlok kaže na kalkiranost (po nem. an, nach $\mathrm{z}$ daj.). 
Osamljen zgled določila INF (19. stoletje, Preš.) v vlogi pravega vsebinskega udeleženca je treba razlagati kot različico SENT, ki se pojavlja ob pogoju enakosti osebka glavnega in odvisnega stavka (slednji se pretvori v INF) in istodobnosti. Vpetost v pesniško besedilo (retorično, stilistično zaznamovano besedilno okolje) opozarja na izrabo posebnih stilističnih vzorcev.

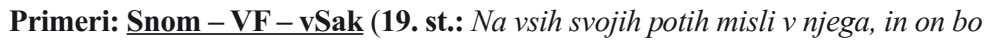
tvoje stopinje vodil. Prg 3,6 W) ${ }^{16}$ Snom - VF - kSdat (10. st.: Da c tomu dini, zinzi, muzlite, ide ne camo ze vcloniti, nu ge pred bosima osima stati i zio prio imeti, iuse gezim bovvedal. BS II, 83-88; 16. st.: Satu nema Predavàz fpet k'fvojmu predanimu blagu mifliti: Ezk 7,13 DB); ${ }^{17}$ Snom - VF - poSlok (16. st.: Vy, kir mejnite, de fte delezh od hudiga dne, inu vfelej le po krivizhnim gofpodovanju miflite, [...] Am 6,3 DB; 19. st.: veliki točaj ne misli po Jožefu več Ravn.). ${ }^{18} \underline{\text { Snom }}$ - VF - oSlok (20. st.: Mislijo o počitnicah v tujini; Dular 1982: 191); $\underline{\text { Snom - VF }}$ - INF (19. st.: Tako, kdor misli trdo stati, pade [...] Preš., Prva ljubezen)

(B) V pomenu (1) se vzpostavlja tudi pomensko razmerje med nosilcem mišljenjskega procesa in procesom samim (izražanje mišljenjske sposobnosti).

Stabilen vezavnostni vzorec je Snom - VF, ki ga gradivo potrjuje od 16 . stoletja naprej. ${ }^{19}$

Primeri: Snom - VF (16. st.: Raunu kakòr de bi Lonzarjeu yl miflil, inu bi enu dellu reklu k'fvojmu Mojftru: On me nej fturil. Iz 29,16 DB; 18. st.: Jeft fim po nozhi v' mojim fèrzi miflil, inu premifhlòval, inu fam febe isprafhòval. Ps 76,7 Jap; 20. st.: Dolgo ni mogel misliti; Ne morem urejeno, zbrano misliti. SSKJ). ${ }^{20}$

${ }^{16}$ Podoben zgled navaja Plet.: $m$. v druge reči 'an andere Dinge denken’ Burg. (Plet. I: 580); glede na nem. prevod ustreza vezljivosti $m$. na koga, kaj 'an jemanden, etwas denken'.

${ }^{17}$ Prim. Darum soll der Verkäufer zu seinem verkeuften Gut nicht wieder trachten (Luter). - Na tem mestu je treba opozoriti na zanimiv zgled določila kSdat v BS. Medtem ko je določilo kSdat v vlogi razmernega vsebinskega udeleženca razmeroma jasno (za stcsl. prim. SJS II: 87; za slov. jezike prim. Kopečný 1973: 104-105), je nekoliko bolj problematičen odvisnik ob njem (tj. ide ne camo ze vcloniti ...). Obravnava se bodisi kot časovni odvisnik z verjetno prilastkovno vlogo (pribl. mislite na tisti dan, ko se ne bo kam skriti ...; Pogačnik 1968: 217; podobno Paternu idr. 2004: 92), R. Kolarič (1968: 51) dopušča ide tudi kot krajevni prislov, bodisi kot namerni odvisnik (želja, da bi se izognili neželenemu dejanju, pribl. mislite na tisti dan, da ne bi kam skrenili ...; Dogramadžieva 1989: 64). Kljub različnim interpretacijam (ob prevladi prve) pa ima odvisnik vlogo nevezljivega dopolnila - dopolnjuje bodisi vezljivo določilo bodisi celotno stavčno strukturo.

${ }^{18}$ Prim. Ona mifli po eni Nyvi ... Prg 31,16 (DB) kaže na precejšnje ujemanje z ... denkt an einem Acker ... (Luter). Na drugačno povezavo opozarja Pleteršnikov zgled iz Dalmatinove Biblije (Plet. I: 580): radi mita jemljo ino mislijo po dareh proti sie haben ein Verlangen nach Geschenken; Ravnikarjev zgled pa spremlja prevod der Mundschenk gedenkt Josefs nicht mehr.

${ }_{19}$ Zgledi predstavljajo sistemsko nerealizacijo določil, ne pa njihovega kontekstualnega izpusta ali absolutne rabe glagola.

${ }^{20} \mathrm{~V}$ zgledih tipa Ne morem urejeno, zbrano misliti; Učenec je logično mislil (SSKJ) je ADV sporočilno obvezno neudeležensko dopolnilo oz. neudeleženski skladenjskoobvezni modifikator glagola (prim. Žele 2003: 30) 
(C) Pomen (1) odpira tudi možnost pomenskega vzorca nosilec mišljenja - razmerni vsebinski udeleženec - vsebina (tudi misliti - o kom, čem-kaj, kako); nosilec mišljenja pripiše razmernemu vsebinskemu udeležencu določeno vsebino.

$\mathrm{Na}$ podlagi gradiva sklepam, da so stabilni vezavnostni vzorci tile: Snom - VF - odSgen - Sak* // SENT in Snom - VF - oSlok - Sak* // SENT. V vlogi vsebine se pojavljata določili Sak* in SENT (več o Sak* v razdelku 2.4.2), odSgen in oSlok pa nastopata v vlogi razmernega vsebinskega udeleženca.

Prvi vezavnostni možnosti se pojavljata do druge polovice 19. stoletja (stabilnejša je možnost z določilom SENT), ko ju zamenjata drugi dve. ${ }^{21}$ Pri razmernem vsebinskem udeležencu pride v 19. stoletju torej do zamenjave, in sicer se odSgen umakne določilu oSlok. Domnevali bi lahko, da je bila omenjena sprememba rezultat sociolingvističnih dejavnikov, tj. vzpostavitve norme, ki kaže na odstranjevanje tujejezičnih oz. neslovanskih prvin iz knj. jezika (za hrv. jezik prim. Hudeček 2003).

Zgodovinskorazvojno je treba določilo odSgen kot razmerni vsebinski predmet omeniti ob glagolih sporočanja in čutenja (vezljivostno sorodni mišljenjskim), npr. brati, govoriti, pisati, povedati, zvedeti itn.; ustaljeno je od 16. (T, D) do 19. stoletja (W), oSlok ga nadomesti šele v 19. stoletju, možnost odSgen pa se ohrani kot pogovorna, npr. pripovedovati (od kralja Matjaža), misliti (Orel 1993: 183, 188-189, 199; Dular 1982: 188-189). ${ }^{22}$ V sodobnem slovenskem jeziku naj bi oSlok vezavno izražal samo razmerni (vsebinski) predmet ob glagolih tipa glasovati, premišljevati itn. (Dular 1982: 191); zgodovinskorazvojno pa je pomenljivo dejstvo, da je I. Orel (1993: 265) v analizi predložnih zvez od 16. do 19. stoletja (na gradivu Mk, 2Mz) zasledila prve primere vsebinskega oSlok ob glagolih sporočanja in čutenja (In Faraon poreče o Izraelovih sinovih [...] 2Mz 14,3) šele v Lampetovih Zgodbah svetega pisma (1895).

Primeri: Snom - VF - odSgen - Sak* (18. st.: Al sa obóje bódo po saflushénju prejęli, sa tó, kęr fo od Bogá hudú miflili, inu na malike dershali, inu sa tó, kęr fo krivú perfęgali, inu Jkusi golùfío pravizo sanizhùváli. Mdr 14,30 Jap; 19. st.: Mislite dobro od Gospoda, in išite ga s priprostim sercam;[...] Mdr 1,1 W); Snom - VF - odSgen - SENT (16. st.: KAdar je pak ta Folk mejnil, inu fo vfi v'fvoim ferci miflili od Ioannefa, aku bi lahkaj

${ }^{21}$ Čeprav sta se vezavnostni možnosti Snom - VF - oSlok - Sak* // SENT pojavili šele v drugi polovici 19. stoletja, ju obravnavam kot stabilni, saj gre za ustaljeno zamenjavo vezavnostnih možnosti z določilom odSgen, v času pojavljanja pa sta tudi stabilni.

${ }^{22}$ F. Kopečný (1973: 154) opozarja, da je predmetni otъSgen 'o' v stč. (praveno jest ot dvú králí), v dluž. (groniš wot cogo; manj gluž.), v sln. (govoriti od koga), v csl. (rečeno ti budetb ot vsěch b, naučeni ot tebe Christ - $\pi \varepsilon \rho i$ бoũ) in v stsbh. (svaku se noć meni od tebe čudno sni; gdi su sad vitezi, od kih pripivaste, Dubr. 16. stoletje) verjetno latinizem, ki je bil v prostorih germansko-slovanskega jezikovnega stika podprt z vplivom nemščine (torej ne gre za goli germanizem, kot je domneval J. Gebauer). V nekaterih primerih lahko prihaja tudi do vezavnostnega križanja (kontaminacije) sinonimnih določilnih možnosti: otъSgen $\leftrightarrow$ oSlok $\rightarrow$ otъSlok, prim. glagolach ot tebě (Lob, hrvcsl.), stč. prorokováchu ot poslednieho věka lidech, stsbh. sami znate, od čem mislite (Dubr., 17. stoletje; Kopečný 1973: 154). 
on Criftus bil, [...] Lk 3,15 DB; 19. st.: [...] prosim vas, de pričujoč ne bom permoran, s tisto serčnostjo derzen biti, s ktero menijo, de sim derzen proti enim, kteri mislijo od nas, de kakor po mesu delamo. 2 Kor 10,2 W); $\underline{\text { Snom }}$ - VF - oSlok - Sak* (19. st.: kako misliš o tej stvari? (Plet. I: 580); 20. st.: Dobro, slabo misli o meni. SSKJ; Večina misli o tem drugače. VSSG); $\underline{\text { Snom }}$ - VF - oSlok - SENT (20. st.: Mislil sem o Mariji, da bo šele jutri prišla domov; Dular 1982: 205).

Kot nestabilen vezavnostni vzorec nastopa Snom - VF - naSak - SENT, ki je izpričan z osamljenim zgledom iz 16. stoletja Vezljivostna »vrednost« vzorca pa je negotova; kompleksnejša besedilna zgradba se lahko razloži kot unija dveh vzorcev, tj. Snom - VF - naSak in Snom - VF - SENT, pri čemer ima določilo naSak vlogo navidezno izpostavljenega udeleženca propozicije SENT (za določila prim. razdelek 2.1.1(A)).

Primer: Snom - VF - naSak - SENT (On bo na fvoje Iunake miflil: Ali vfaj bodo tijfti padli, kamer kuli bodo hotéli pojti, inu bodo k'Sydu hitéli, inu h'tej brambi, ker bi shiher bily. Nah 2,5 DB).

2.1.2 Pri pomenu (2) 'nameravati' so izpričane tele desne določilne možnosti:

Desne določilne možnosti sln. misliti v pomenu (2)

\begin{tabular}{|l|l|l|c|c|c|c|}
\hline & $\begin{array}{l}\text { Predknj. } \\
\text { obdobje }\end{array}$ & 16. st. & 17. st. & 18. st. & 19. st. & 20. st. \\
\hline naSak & & & & & & $\square$ \\
\hline INF & & $\square$ & $\square$ & $\square$ & $\square$ & $\square$ \\
\hline SENT & & & & & & $\square$ \\
\hline
\end{tabular}

Legenda:

$\square \quad$ gradivsko izkazana določilna možnost

(A) V primeru pomena (2) je vzpostavljen pomenski vzorec nosilec namere-vsebina. Na podlagi gradiva sklepam, da je stabilen vezavnostni vzorec samo Snom - VF - INF, v katerem vlogo vsebinsko-namernega udeleženca pokriva tipično določilo INF.

Glagol misliti v pomenu 'nameravati', ki se približuje pomožniški vlogi (podobno je pri naklonskih, faznih glagolih), zahteva določilo INF (ki tu ne predstavlja pretvorbne možnosti SENT ob določenih slovničnih pogojih).

Primeri: Snom - VF - INF (16. st.: Inu jeft fim miflil tebi zhaft iskasati, ali GOSPVD nej pèrpuftil tebi zhaft iskasati. $4 \mathrm{Mz} 24,11 \mathrm{DB} ; 18$. st.: Jeft fim miflil sydati hifho, v'katęri bi pozhivala Jkrinja savęse Gofpódove, inu podnóshje nôg nafhiga Bogá: inu fim k’sidánju vfe perprávil. 1 Krn 28,2 Jap; 20. st.: Misli kupiti to blago; Mislil je govoriti z njim. VSSG). 
Nestabilna vezavnostna vzorca sta Snom - VF - naSak in Snom - VF - SENT. V primeru pomena (2) sta obrobna (celo vprašljiva) - z redkimi zgledi sta zabeležena le v 20. stoletju. Možno je, da predstavljata samo stilistično izrabo vezavnostnih možnosti, značilnih za pomen (1), čeprav vsaj določilo naSak kaže na izhodiščni pomenski odtenek smernosti, namere. ${ }^{23}$

Primeri: Snom - VF - naSak (20. st.: Ali že misliš na odhod, na upokojitev? SSKJ); Snom - VF - SENT (20. st.: Mislil je, da pride. VSSG).

2.1.3 Pri pomenu (3) 'misliti, snovati v škodo/korist' je izpričanih pet desnih določilnih možnosti:

Desne določilne možnosti sln. misliti v pomenu (3)

\begin{tabular}{|l|c|c|c|c|c|l|}
\hline & $\begin{array}{l}\text { Predknj. } \\
\text { obdobje }\end{array}$ & 16. st. & 17. st. & 18. st. & 19. st. & 20. st. \\
\hline zoperSak & & $\square$ & $\square$ & $\square$ & $\square$ & \\
\hline Sak* - Sdat & & $\square$ & $\square$ & $\square$ & $\square$ & \\
\hline Sak* - čezSak & & $\square$ & $\square$ & $\square$ & & \\
\hline Sak* - zoperSak & $\square$ & $\square$ & $\square$ & $\square$ & \\
\hline Sak* - sSins & & & & & $\square$ & \\
\hline
\end{tabular}

Legenda:

$\square \quad$ gradivsko izkazana določilna možnost

- drugače izkazana oz. domnevana določilna možnost (prim. op. 8)

(A) V primeru pomena (3), ki ga lahko umestimo v čas od 16. do 19. stoletja, je vzpostavljen pomenski vzorec nosilec mišljenja - vsebina - prejemnik, ki odraža vezljivostno razmerje z vsebino (običajno negativno), ${ }^{24} \mathrm{ki}$ jo nosilec misli proti prejemniku.

$\mathrm{Na}$ podlagi gradiva sklepam, da sta stabilna vezavnostna vzorca predvsem Snom - VF - Sak* - Sdat // zoperSak; prav tako stabilen, čeprav izkazan v krajšem časovnem obdobju (16.-18. stoletje), je vzorec Snom - VF - Sak* - čezSak.

Določilo Sak* nastopa v vlogi vsebinskega udeleženca (več v 2.4.2), v vlogi prejemnika pa se pojavljajo določila Sdat, zoperSak in čezSak. Ob ustaljeni prejemniški vlogi določila Sdat, ki izhaja iz pomena smernosti (Pogorelec 1968: 146;

23 J. Dular (1982: 194) uvršča določilo SENT v tovrstnih primerih med ciljne predmete, ki nastopajo pri glagolih z izrazito hotenjsko sestavino; v tej vlogi pa naj bi bili vsebinski oz. natančneje da-jevski odvisniki redki.

${ }^{24}$ Ni pa nujno (vsaj v primeru vzorca Snom - VF - Sak* - Sdat), prim. dobro m. komu es mit jemandem gut meinen, Levst. (Rok.) (Plet. I: 580), medtem ko je pomen protivnosti pri določilih čezSak, zoperSak preveč plastičen, da bi dovoljeval »pozitivno« vsebino. Določilo Sak* v vlogi vsebinskega udeleženca ima skoraj predmetno vlogo (prim. hudo, dobro 'slabe, dobre stvari'). 
Večerka 1993: 262), ${ }^{25}$ pa je treba opozoriti na dodatni protivnostni odtenek in na morebitno kalkiranost določil zoperSak, čezSak (po nem. vzoru). ${ }^{26}$

Primeri: Snom - VF-Sak* - Sdat (16. st.: Kadar je pak David vidil, de je Saul njemu hudu miflil, je on rekèl k'Farju AbIataru: Sesi po Ephod. 1 Sam 23,9 DB; [...] iz serca nemu voisčimo inu mislimo dobru. TC 1555 (I, 409); 19. st.: Vernejo naj se, in sram jih bodi, ki mi hudo mislijo. Ps 34,4 W); Snom - VF - Sak* zoperSak (16. st.: [...] de ti hočeš meni odpustiti vse muye grehe inu kar sem danas hudiga subper tuyo volo inu zapuvid mislil, govurill oli sturill. TA (I, 307); 19. st.: Nič več ni vriskanja v Moabu; zoper Hesebon hudo mislijo. Jer 48,2 W); ${ }^{27}$ Snom - VF - Sak* - čezSak 16. st.: Vfi, kateri mene fovrashio, vkup Jhapazheo supàr mene, inu hudu zhes me miflio. Ps 41,8 DB; 18. st.: Katęri zhes mene hudú míflio, imajo nasaj bejshati, inu k'framoti poftati. Ps 34,4 Jap).

K nestabilnim vezavnostnim vzorcem z zadržkom spada Snom - VF - Sak* - sSins, izkazan z osamljenim zgledom iz 19. stoletja. V vlogi prejemnika $\mathrm{v}$ tem primeru nastopa določilo sSins ${ }^{28}$ (določilo Sak* kot vsebina), a se zdi tovrstna interpretacija negotova; zgled se lahko razloži tudi z elipso glagola v nedoločniškem polstavku (misliti storiti), kar bi pričalo o pomenu (2) in določilu INF. ${ }^{29}$

${ }_{25}$ Za sodobni slovenski jezik J. Dular (1982: 200) navaja, da je Sak - Sdat »ena najpogostejših kombinacij v dvojni vezavi«, pri čemer Sak izraža vsebinski (ali zadeti) predmet, Sdat pa ciljni (redkeje razmerni) predmet.

26 Etimološko se sln. zộper razlaga kot poprisl. samostalnik psl.*sópbr'b s prvotnim pomenom *'nasprotnik' (Snoj 2003: 859), psl. *čerz(ъ) 'prek, čez' pa naj bi izhajal iz ide. prislova *(s)kertsom 'prek' (Snoj 2003: 86); med pomeni slednjega se omenja tudi protivnostni, prim. stcsl. i ničto že čresb volju ichъ tvoriti - vzhcsl. črězъ volju gospodonju - sln. čez čast komu kaj reči (Kopečný 1973: 51). Protivnostna vloga (predmet nasprotovanja, negodovanja, napadanja) določil je dobro izkazana v zgodovini slovenskega jezika (Orel 1993: 416-417, 426-429; Dular 1982: 188, 198, 201). Določilni možnosti Sak* - zoperSak // čezSak kažeta pri J. Dalmatinu na ujemanje z Lutrovo predlogo, prim. zoper - wider, čez-über.

27 Zanimivi so v tem kontekstu zgledi z zapostavljenim predlogom zoper in daj., prim. V tih Dessetih zapuvidah ie ta večna, prava, sveta vola Božya zapopadena, obtu kar se takim zapuvidom zubper misli, govori oli sturi, tu istu ie vselei Bogu zubper inu greh. TO (III, 338); ... inu si čestukrat Bogu inu nega bessedi zubper mislil, govuril inu sturil ... TO (III, 506). Stičnost predloga (prislova) in glagola bi lahko pomenila približevanje glag. sestavljenkam s prislovno-predložno sestavino v vlogi predpone (glagolski kalk po nem. vzorcu) tipa zoper misliti (prim. zoper stati; Merše 2003: 81-83, 92; Vidovič-Muha 1984).

28 Osnovni (splošnoslov.) pomen predložne zveze sъ(n)Sins naj bi bil spremljevalni, npr. sln. potovati s kom; z njim sta povezana vsebinski (npr. češ., slk. hrnec s vodou, češ. děvče s modrýma očima) ter sredstveni pomen (blizu načinovnemu, prim. sln. konj se brani s krepko nogo; Kopečný 1973: 244-248; Orel 1993: 355-356). Zgodovinskorazvojno bi se lahko sSins ob misliti povezal z razmernim predmetom (prim. vfe kar je Bug bil fturil s'Moseffom, inu s'fvoim Israelfkim folkom 2Mz 18.1 Jap), določitev vloge prejemnika dejanja pa bi temeljila na sopomenskih določilnih možnostih Sak* - Sdat // čezSak // zoperSak.

29 Prim. zglede elipse iz 20. stoletja (ob pomenu (2)): $k$ njemu sem mislil SSKJ (557); $V$ Nemčijo je mislil z letalom VSSG (207); v tem primeru bi imel sSins v polstavku vlogo dopolnila ali razmernega predmetnega udeleženca. 
Primer: Snom - VF - Sak* - sSins (Vi ste z menoj hudo mislili; Bog pa je tisto obernil $v$ dobro, ker me je povikšal, kakor zdaj vidite, de je otel veliko ljudstva. Gen 50,20 W).

(B) Pomenskemu vzorcu nosilec mišljenja - vsebina - prejemnik ob pomenu (3) ustreza dokaj stabilen »reduciran« vezavnostni vzorec Snom - VF - zoperSak, ki določilno izkazuje nosilca (Snom) in prejemnika (zoperSak), negativna vsebina mišljenja pa se razume sobesedilno (že iz minimalne besedilne realizacije vzorca).

Primeri: Snom - VF - zoperSak (16. st.: Potle on fpet domou pojde, s'velikim blagom, inu njegovu ferce bo miflilu supèr to fveto Saveso, ondi bo on nekuliku opravil, inu taku domou, v'fvojo Deshelo fhàl, [...] Dan 11,27 DB; 19. st.: Napačna je ta vaša misel, kakor de bi bil zoper lončarja mislil, in delo svojimu delavcu reklo: [...] Iz 29,16 W).

\subsection{Vezljivost glagola MNETI}

2.2.1 Sln. mneti s pomenom 'meniti' izkazuje med desnimi določilnimi možnostmi SENT in Sak - SENT. Obe sta izkazani le z zgledom iz 16. stoletja (nestabilnost). Ob tem naj še enkrat poudarim, da se glagol pojavlja le v gradivu iz 16 . stoletja (pri P. Trubarju), kasneje ga namreč nadomesti konkurenčni meniti (prim. razdelek 1.2).

(A) Pri pomenu 'meniti' je vzpostavljen pomenski vzorec nosilec mišljenja - vsebina. Pomenskemu razmerju ustreza zgled vezavnostnega vzorca Snom - VF - SENT. Določilo SENT pokriva vlogo vsebinskega udeleženca propozicijskega tipa, tj. kompleksne vsebine mišljenjske dejavnosti.

Primer: Snom - VF - SENT (16. st.: Vi ne imate mneti, de fem ieft prishal hposhilanu ta myr [...] Ta pervi deil ... 1557, 28).

(B) Pomen 'meniti' odpira tudi pomenski vzorec nosilec mišljenja - prizadeto vsebina; nosilec mišljenja pripiše vsebinskemu udeležencu (tip prizadeto) določeno vsebino, lastnost prek predikativnega stavčnega člena.

Pomenskemu razmerju ustreza zgled vezavnostnega vzorca Snom - VF Sak - SENT. Določilo Sak se v vezljivostni možnosti približuje vlogi prizadeto, SENT pa predikativni vrednosti. ${ }^{30}$

Primer: Snom - VF - Sak - SENT (16. st.: Gledaite tedai, koku ui poslushate. Sakai kateri ima timu bode danu, kateri pag nema od tiga bode tudi tu ufetu kar on mni de ima. Lk 8,18, Ta celi novi ... 1581-1582).

30 Zgled se lahko obravnava tudi kot posebna besedilna realizacija vzorca Snom - VF SENT z izpostavljenim členom iz vsebinskega odvisnika, vendar njegova osamljenost onemogoča zanesljivejše sklepanje. 


\subsection{Vezljivost glagola MENITI}

2.3.1 Pri pomenu (1) 'meniti, misliti, imeti za' so izpričane tele desne določilne možnosti:

Desne določilne možnosti sln. meniti v pomenu (1)

\begin{tabular}{|l|c|c|c|c|c|c|}
\hline & $\begin{array}{l}\text { Predknj. } \\
\text { obdobje }\end{array}$ & 16. st. & 17. st. & 18. st. & 19. st. & 20. st. \\
\hline Sak & & $\square$ & $\square$ & $\square$ & $\square$ & $\square$ \\
\hline SENT & & $\square$ & $\square$ & $\square$ & $\square$ & $\square$ \\
\hline Sak* odSgen & & & & & $\square$ & \\
\hline Sak* - oSlok & & & & & & $\square$ \\
\hline Sak*-sSins & & $\square$ & & & & \\
\hline Sak - SENT & & $\square$ & - & $\square$ & $\square$ & \\
\hline zaSak - SENT & & & & & & $\square$ \\
\hline odSgen-SENT & & $\square$ & - & $\square$ & $\square$ & \\
\hline oSlok - SENT & & & & & & $\square$ \\
\hline ADV & & $\square$ & - & $\square$ & $\square$ & $\square$ \\
\hline
\end{tabular}

Legenda:

gradivsko izkazana določilna možnost

- drugače izkazana oz. domnevana določilna možnost (prim. op. 8)

(A) V pomenu (1) se vzpostavlja pomenski vzorec nosilec mišljenja - vsebina. Na podlagi gradiva sklepam, da sta med stabilnimi vezavnostnimi vzorci pogosta Snom - VF - Sak in Snom - VF - SENT. Določilo SENT nastopa v vlogi vsebinskega udeleženca propozicijskega tipa, medtem ko je Sak v vlogi nepropozicijskega vsebinskega udeleženca redkejše (več o desnih določilih v razdelku 2.1.1(A)).

Domnevam, da se stabilno (od 16. stoletja do danes) pojavlja tudi vzorec Snom - VF - ADV, s t. i. nadomestnim določilom ADV v vlogi vsebinskega udeleženca (na mestu Sak, SENT; več o določilu ADV, tudi s primeri, v razdelku 2.4.1).

Primeri: Snom - VF - Sak (16. st.: Od kateriga, ty toshniki, kir fo v'prizho ftali, néfo obeniga tiga urfaha naprej pèrnefli, katere fim jeft mejnil. Apd 25,18 DB; 18. st.: On je pak mejnil Judesha Ifhkarjóta Șimónoviga:[...] Jn 6,72 Jap; 20. st.: Očeta menim, ne tebe; Koga menite? VSSG); Snom - VF - SENT (16. st.: Mejnifh li, de hozhefh satu Krajl biti, kir s'Cedrom prangafh? Jer 22,15 DB; 18. st.: Mejnifh li, de Se ti pravizhnu jesifh savolo bèrfhlina? Jon 4,9 Jap; 20. st.: Menijo, da je bila stavba zgrajena $v$ desetem stoletju. SSKJ; tudi brezvezniško: v gradivu iz 16. stoletja prim. IEft mejnim pak, Bug je nas Apoftole, sa te nar manfhe naprej poftavil, kakòr te, kir fo v'fmèrt isdani. 1 Kor 4,9 DB; Ieft mejnim pak letu: Kateri Jkopu Jeje, ta bo tudi fkopu shèl, [...] 2 Kor 9,6 DB).

(B) V pomenu (1) se vzpostavlja tudi pomensko razmerje, v katerem nosilec mišljenja pripiše vsebinskemu udeležencu (tipa prizadeto) vsebino, lastnost prek predikativnega stavčnega člena (pomenski vzorec nosilec mišljenja - prizadeto - vsebina). 
Gradivsko dokaj stabilen vezavnostni vzorec, ki ustreza pomenskemu razmerju, je Snom - VF - Sak - SENT; izpričan je z redkejšimi zgledi iz 16. stoletja in iz 18. -19 . stoletja.

Primeri: Snom - VF - Sak - SENT (16. st.: Sakaj ony fo v'Méfti shnym bily vidili, Trophima tiga Epheserja, tiga fo ony mejnili, de bi ga bil notèr v'Tempel pèrpelal. Apd 21,29 DB; 19. st.: [...] in ude telésa, ki menimo, de so menj častitljivi, njé z obilniši častjo obdajamo; in kteri so nespodobni na nas, se z obilniši spodobnostjo pokrivajo. 1 Kor 12,23 W).

(C) Pomen (1) odpira tudi možnost pomenskega vzorca nosilec mišljenja - razmerni vsebinski udeleženec - vsebina (tudi misliti - o kom, čem-kaj, kako); nosilec mišljenja pripiše razmernemu vsebinskemu udeležencu določeno vsebino.

$\mathrm{Na}$ podlagi gradiva sklepam, da so stabilni vezavnostni vzorci tile: Snom VF - odSgen - Sak* // SENT in Snom - VF - oSlok - Sak* // SENT. V vlogi vsebine se pojavljata določili Sak* in SENT (več o določilu Sak* v 2.4.2), odSgen in oSlok pa nastopata v vlogi razmernega vsebinskega udeleženca (prim. tudi 2.1.1(C)).

Pri zadnjem v 19. stoletju nastopi zamenjava določila, in sicer odSgen zamenja oSlok (oSlok se v tej udeleženski vlogi pred drugo polovico 19. stoletja ne pojavlja). ${ }^{31}$

Primeri: Snom - VF - odSgen - Sak* (19. st.: [...] tega pa nisim menil od kurbirjev tega svetá, ali od lakomnikov, ali od roparjev, ali od malikovavcov; sicer bi mogli iz tega svetá iti. 1 Kor 5,10 W); Snom - VF - odSgen - SENT (16. st.: KAdar je pak ta Folk mejnil, inu fo vfi v'fvoim ferci miflili od Ioannefa, aku bi lahkaj on Criftus bil, [...] Lk 3,15 DB; 19. st.: Zakaj ako kdo od sebe méni, de je kaj, ker nič ni, sam sebe zapelje. Gal 6,3 W); Snom - VF-oSlok Sak* (20. st.: Kaj meniš o vsem skupaj? VSSG); Snom - VF - oSlok-SENT (20. st.: O tem problemu so menili, da ni dobro rešen. SSKJ).

Nestabilen vezavnostni vzorec, ki ustreza pomenskemu razmerju, je Snom - VF zaSak - SENT (osamljen zgled iz 20. stoletja).

Določilo zaSak zaznamuje izhodiščna ciljnost (Kopečný 1973: 283-284). J. Dular (1982: 188) opozarja, da zaSak izraža vsebinski predmet izjemoma (vedeti za skrivni izhod); med glagoli mišljenjskega (ali sorodnega) pomena, ob katerih se je v zgodovini slovenskega jezika pojavljalo določilo zaSak, se lahko navedejo vprašati, prositi (ustaljeno), moliti (T) (zaSak - cilj dejanja), marati za koga (T, D), biti mar za koga/kaj (Jap, W) (zaSak - prejemnik dejanja), vedeti, skrbeti (Jap) (zaSak - vsebina dejanja; Orel 1993: 340-341, 350).

Primer: Snom - VF - zaSak - SENT (20. st.: Za ta problem so menili, da ni dobro rešen. SSKJ).

${ }^{31}$ Povzemalno: Vezavnostni možnosti (a) Snom - VF - odSgen - Sak* // SENT se pojavljata od 16. do 19. stoletja; pri tem se možnost s SENT pojavlja v 16. in 19. stoletju (domnevam stabilno pojavljanje tudi v 17. in 18. stoletju), Sak* pa le v 19. stoletju. Pri Sak* bi tudi lahko - upoštevajoč možnost zaimenskega določila - sklepali na stabilno pojavljanje v starejših obdobjih. Vezavnostni možnosti (b) Snom - VF - oSlok - Sak* // SENT se stabilno pojavljata od druge polovice 19. stoletja naprej. 
(Č) Pomen (1) kaže tudi na vezljivostno možnost, ko nosilec mišljenja vzpostavlja pojasnjevalno pomensko razmerje med vsebinskim (Sak*) in razmernim udeležencem (sSins); prim. pomenski vzorec misliti - kaj, kako-s čim.

Pomenskemu razmerju ustreza nestabilen vezavnostni vzorec Snom - VF - Sak* - sSins, ki je gradivsko izpričan z redkimi zgledi iz 16. stoletja. ${ }^{32}$ Zgodovinskorazvojno se lahko sSins ob meniti poveže z abstraktnim sredstvom dejanja (Orel 1993: 369-370, 372). ${ }^{33}$

Primeri: Snom - VF - Sak* - sSins (Inu vus folk fe je okuli k'njemu obèrnil, inu ga vprafhal, kaj bi on s'takovimi beffedami mejnil? DanD 1,47 DB; Na tu ti imaš se vučiti inu veiditi, nekar le samuč de le-ta bolezan od Buga inu ž nega volo ie tebi naložena, temuč ti se tudi imaš vučiti inu veiditi, kai Bug s tako bolezanio meni inu zakai ie on no tebi nalužil. TO (III, 513).

2.3.2 Pomen (2) 'nameravati' kaže na pomenski vzorec nosilec namere - vsebina. Gradivsko stabilen vezavnostni vzorec, ki ustreza pomenskemu razmerju, je Snom - VF - INF (gradivo ga izkazuje od 16. stoletja do danes). Določilo INF je za vlogo vsebinsko-namernega udeleženca propozicijskega tipa najbolj tipično.

Primeri: Snom - VF - INF (16. st.: Tu je en nedomiffeln Zhlovik, kateri mejni fvoj fvit Jkriti. Satu Jposnam jeft, de fim jeft preproftu govuril, [...] Job 42,3 DB; 17. st.: [...] kadar meinimo shiveiti, shiveine od nas beishij, inu h'konzu fe perblishuje. SJJSv; 20. st.: Nisem te menil prizadeti. VSSG).

2.3.3 V primeru pomena (3) 'reči, dejati', izpričanem samo za 20. stoletje, je vzpostavljeno pomensko razmerje med nosilcem sporočanja in sporočano vsebino (pomenski vzorec nosilec sporočanja - vsebina). ${ }^{34}$

Na podlagi gradiva domnevam, da razmerju ustrezata dva nestabilna vezavnostna vzorca, in sicer Snom - VF - SENT // PG (z osamljenimi zgledi iz 20. stoletja); določili SENT in PG sta sicer tipični za vlogo kompleksnega vsebinskega udeleženca (tj. vsebine sporočanja).

Primeri: Snom - VF - SENT (20. st.: Oče meni, da to ni prav. VSSG); Snom -VF-PG (20. st.: To ni lepo in prav, meni oče; Lahko greste, meni zaničljivo, toda prej plačajte. SSKJ).

${ }^{32}$ V primeru vezavnostnega vzorca Snom (1) - meniti - Sak (2) - sSins (3) (npr. S tem menim hišo) je vzpostavljena zveza z relacijskim pomeniti, prim. Snom (3) - pomeniti - Sak (2) (npr. To pomeni hišo). Z določilno možnostjo Snom - VF - Sak - sSins »tekmuje« Snom - VF - Sak, v prid katere bi mogoče govorili dve točki: (a) redki zgledi iz 16. stoletja ; (b) potencialna opustljivost sSins (tj. vloga dopolnila).

${ }^{33}$ I. Orel ne navaja zgledov, podobnih tistim ob meniti (določilo sSins); slednji se kljub temu lahko opredelijo kot sredstveni - gre namreč za predmetnost, s katero se opravlja, uresničuje dejanje (Orel 1993: 379).

${ }^{34}$ Po jezikovnem občutku sodim, da je v sodobnem slovenskem jeziku 'reči, dejati' (z določilnimi možnostmi) najbolj obroben med pomeni glagola meniti. 


\subsection{Prislovno določilo ob glagolih mišljenja v slovenskem jeziku}

V raziskavi se med določilnimi možnostmi ob glagolih mišljenja v slovenskem jeziku pojavlja tudi določilo Sak* oz. ADV, in sicer na položaju vsebinskega udeleženca. Večinoma zaimenski (kakovostni, količinski) prislovi v takšnih primerih besedilno nadomeščajo določilo SENT, ki sicer najbolj nazorno upodablja kompleksno propozicijsko vsebino; Sak* oz. ADV nastopata torej kot »eine Art stellvertretender Ergänzung« (Ágel 2000: 261). Tudi v okvirih češke vezljivostne skladnje ima takšen ADV posebno vlogo, saj predstavlja t. i. neeksplicitno vsebino - jo le naznačuje (splošno, nedoločno ali kolikostno), prim. Neslíbil mu nic; Pověděl toho málo itn. (VV 1987: 161).

Na podlagi gradiva in vezljivostne analize glagolov mišljenja je bilo mogoče vzpostaviti dva tipa določila Sak* oz. ADV.

\subsection{1 »Nadomestno« določilo ADV kot samostojna določilna možnost}

ADV v vlogi t. i. nadomestnega določila (vezavnostni vzorec Snom - VF - ADV) predstavlja neeksplicitno vsebino; vsebinskega udeleženca zastopajo večinoma zaimenske (predvsem kakovostne) prislovne oblike, ki le besedilno zapolnjujejo določilno mesto, predvideno za kompleksno propozicijsko realizacijo SENT.

V zgodovini slovenskega jezika se je vzorec Snom - VF - ADV pojavljal ob misliti v pomenu (1) 'misliti, razmišljati' in meniti v pomenu (1) 'meniti, misliti, imeti za'; gradivo izpričuje stabilne zglede iz 16. stoletja in 18.-19. stoletja (podobni zgledi se lahko navedejo tudi za 20.-21. stoletje). V obeh primerih gre za pomenski vzorec nosilec mišljenja - vsebina.

Primeri: meniti (16. st.: Isvprafhaj mene Bug, inu Jkusi moje ferce: Probiraj mene, inu fposnaj, koku jeft mejnim. Ps 139,23 DB; 19. st.: On pa ne bo tako menil, in njegovo serce ne bo tako mislilo, ampak zatreti ga bo želel, in končati veliko narodov. Iz 10,7 W); misliti (16. st.: Aku on lih taku nemejni, inu njegovu fàrze taku nemifli, temuzh njegovu fàrze ftoji satréti, inu konzhati nikar malu folkou. Iz 10,7 DB; 18. st.: Ampak de bóte popólnoma enaku miflili, inu mejnili. 1 Kor 1,10 Jap; 19. st.: In ko je Jezus zdajci v svojim duhu spoznal, de sami per sebi takó mislijo, jim je rekel: [...] Mr 2,8 W).

\subsection{2 »Nadomestno« določilo Sak* kot del desne določilne možnosti}

ADV se v vlogi t. i. nadomestnega določila lahko pojavlja tudi kot del desnih določilnih možnosti (Sak*). Določilo Sak* neeksplicitno vsebino na poseben način nominalizira in se tako približuje vlogi predmetnega določila Sak; posledica tega približevanja je prekrivnost z zaimenskimi neprislovnimi prvinami, ki so potencialno zamenljive s kakovostnimi zaimenskimi prislovi, prim. To mislim o njem $\rightarrow$ Tako mislim o njem itn. ${ }^{35}$ »Nadomestno« določilo pomensko variira (tj. je bolj/

35 Oznaka Sak* zastopa torej prislovne in sopomenske neprislovne oblike, ki besedilno nadomeščajo kompleksnejše določilo z vsebinsko udeležensko vlogo. Pritegnitev neprislovnih oblik v skupino upravičujeta pojavljanje v enakih vezljivostnih kontekstih (vezavnostnih vzorcih) in zamenljivost s prislovnimi določili. 
manj povedno, se bolj/manj približuje pravemu določilu itn.) glede na vezavnostni vzorec, leksikalno zapolnitev. V nadaljevanju navajam vezavnostne možnosti (z ilustrativnim zgledom), v katerih se pojavlja prislovni »nadomestni« Sak*; natančnejši podatki v zvezi z določilnimi možnostmi so $\mathrm{v}$ predstavitvah vezljivosti glagolov mišljenja (gl. razdelke 2.1.1(C), 2.1.3(A), 2.3.1(C) in 2.3.1(Č)).

V zgodovini slovenskega jezika se je določilo Sak* pojavljalo kot del desnih določilnih možnosti predvsem ob glagolu misliti v pomenih (1) 'misliti, razmišljati' (pomenski vzorec nosilec mišljenja - razmerni vsebinski udeleženec - vsebina; vezavnostna vzorca Snom - VF - odSgen // oSlok - Sak*) in (3) 'misliti, snovati v škodo/korist' (pomenski vzorec nosilec mišljenja - vsebina - prejemnik; vezavnostni vzorci Snom - VF - Sak* - Sdat // zoperSak // čezSak // sSins); osamljen zgled (16. stoletje) ob meniti v pomenu (1) 'meniti, misliti, imeti za' (pomenski vzorec nosilec mišljenja - vsebina - razmerni udeleženec, prim. misliti - kaj, kako - s čim; vezavnostni vzorec Snom - VF - Sak* - sSins) je negotov. ${ }^{36}$

Primeri: misliti (1) Snom - VF - odSgen - Sak* (18.-19. stoletje, npr. 19. st.: Mislite dobro od Gospoda, in išite ga s priprostim sercam; [...] Mdr 1,1 W); Snom - VF - oSlok - Sak* (19.-20. stoletje, npr. 20. st.: $\underline{\text { Dobro }}$ slabo misli o meni. SSKJ); misliti (3) Snom - VF - Sak* - Sdat (16.-19. stoletje, npr. 16. st.: Kadar je pak David vidil, de je Saul njemu hudu miflil, je on rekèl k'Farju AbIataru: Sesi po Ephod. 1 Sam 23,9 DB); Snom - VF - Sak* - zoperSak (16.-19. stoletje, npr. 19. st.: Nič več ni vriskanja v Moabu; zoper Hesebon hudo mislijo. Jer 48,2 W); Snom - VF - Sak* - čezSak (16.-18. stoletje:, npr. 18. st.: Katęri zhes mene hudú míllio, imajo nasaj bejshati, inu k'framoti poftati. Ps 34,4 Jap); Snom - VF - Sak* - sSins (osamljeno, 19. st.: Vi ste z menoj hudo mislili; Bog pa je tisto obernil v dobro, ker me je povikšal, kakor zdaj vidite, de je otel veliko ljudstva. Gen 50,20 W).

Prislovi in prislovne zveze so običajno del neobvezne družljivosti, le del se uvršča v vezljivost: obveznovezljiva prostorska, časovna prislovna določila ob glagolih tipa stanovati (doma), trajati (tri ure) in pomenskoskladenjsko obvezna nevezljiva dopolnila (izpridevniški prislovi), prim. Lepo je pisala. Zadnji ADV je t. i. lastnostni modifikator (izraža vrednotenje, kolikost, kratnost), ki ni del povedkovodoločilne vezljivosti (tipa Bilo mu je lepo), je pa sporočilno obvezno neudeležensko dopolnilo oz. neudeleženski skladenjskoobvezni modifikator glagola (Žele 2003: 30). ${ }^{37}$

Povedkova lastnostna prislovna dopolnila se lahko opredelijo nivojsko: (1) so obveznodružljiva oz. pomenskoskladenjsko obvezna, sporočilo natančneje konkretizirajo; (2) z vidika soodvisnosti glagolov in prislovnih dopolnil so najbolj obvezna dopolnila ob glagolih ravnanja, stanja, poteka/procesa (pomenska nadsestavi-

${ }^{36}$ Prim. 16. st.: Oča serce k nom obernil, resničnu ye on s teim meinil, z nai žlahtnišim nas rešil. TAr (III, 58).

${ }^{37}$ A. Žele (2001: 18) navaja med določili tudi okoliščinska, med katere spadajo $\left(\mathrm{d}_{1}\right)$ udeležensko obvezna (živeti doma), $\left(\mathrm{d}_{2}\right)$ udeležensko neobvezna (živeti sedaj), $\left(\mathrm{d}_{3}\right)$ neudeleženski modifikatorji (dobro, lepo, brezskrbno živeti). 
na 'odnos'), ki 'vedenje' ali 'razmerje' lastnostno, vrstno, primerjalno opredeljujejo (premikajo se v smeri tipične glagolske kolokacije); ${ }^{38}$ (3) glagoli so potencialni pomenskoskladenjski pobudniki obveznodružljivih zvez (prim. Žele 2007).

Primeri tipa 2.4.1 (prim. 19. st.: On pa ne bo tako menil, [...]) in 2.4 .2 (prim. 20. st.: Dobro misli o meni.) se oddaljujejo od zgornjih opredelitev povedkovih dopolnil; ADV oz. Sak* se namreč nahaja na položaju določila, kar je razvidno iz razmerij meni, da je ravnal pravilno - meni tako; o njem misli dobro - o njem misli dobre stvari, misli ji dobro - misli ji dobre stvari.

ADV oz. Sak* se vlogi določila približuje s položaja lastnostnega prislovnega dopolnila; oddaljevanje od slednjega zaznamuje tole: (1) vloga konkretizatorja sporočila se krepi, na kar vpliva povečana pomenskoskladenjska obveznost; (2) slabi lastnostno opredeljevanje 'vedenja' ali 'razmerja' (večji vsebinski pomen), kolokacijsko so zveze stabilne; ${ }^{39}$ (3) glagoli odpirajo vezljivostna mesta, ki niso zasedena s pričakovanim določilom, temveč se na mestu določila nahaja ADV. Glede na skladenjsko obnašanje ADV oz. Sak* menim, da se pojavljata na položaju določila - kot tip »nadomestnega« določila (prim. Ágel 2000: 261).

\section{$3 \quad$ Primerjava vezljivosti glagolov mišljenja v slovenskem jeziku (s poudarkom na vezavi)}

\subsection{Pomeni glagolov mišljenja}

Slovenski glagoli mišljenja, tj. misliti, mneti, meniti, izkazujejo tele primerljive pomene:

Pomeni glagolov mišljenja

\begin{tabular}{|l|c|c|c|}
\hline & misliti & mneti & meniti \\
\hline (a) 'misliti, meniti' & $\mathbf{( 1 )}$ & (1) & (1) \\
\hline (b) 'nameravati' & $\mathbf{( 2 )}$ & & (2) \\
\hline (c) 'misliti, snovati v škodo/korist' & $\mathbf{( 3 )}$ & & \\
\hline (̌c) 'reči, dejati' & & & (3) \\
\hline
\end{tabular}

38 Med glagoli govorjenja, razumevanja, mišljenja naj izpostavim predvsem misliti (lahko, zato, resno, osebno, tako kot on) ter razumeti (lahko, mogoče, dobro, težko, prav, napačno) itn. (Žele 2007: 383-384).

${ }^{39}$ Zgradbe tipa misliti dobro o njem, misliti dobro komu kažejo na nadomestno vlogo Sak*: slednji izhodiščno nastopa kot lastnostni modifikator verjetno propozicijskega SENT, prim. Mislim o njem, [da je uspešen, da je pošten itn.] $\rightarrow$ [to je dobro] $\rightarrow$ Mislim o njem dobro; Mislim mu [dobre stvari] $\rightarrow$ Mislim mu dobro. V teh primerih nastopa dobro na mestu določila (še bolj razvidno v zgradbah meniti tako z zaimenskim prislovom), pri čemer slednjega na poseben način nominalizira (tudi zato oznaka Sak*). V razmerju $m i$ sliti dobro, tekoče, resno $\leftrightarrow$ misliti dobro, slabo o njem; misliti mu dobro, slabo postane razviden sinkretizem ADV, ki ima lahko vlogo lastnostnega modifikatorja ali določila. 
3.2 Stabilnost pomenov glagolov mišljenja in njihove vezavnostne možnosti 3.2.1 Pomen (a) 'misliti, meniti'

Pomen 'misliti, meniti' izkazujejo glagoli misliti (1), mneti (1), meniti (1). Pri misliti, meniti je pomen potrjen za obdobje od 16. do 21. stoletja (pri misliti tudi v 10. stoletju), pri glagolu mneti pa so zgledi samo iz 16. st. (kar velja tudi za sam glagol). Glagol meniti izkazuje še podpomen 'imeti za' (mogoče tudi mneti), kar bi lahko vplivalo na vezljivostne lastnosti.

(A) Vezavnostne možnosti pomena (a) 'misliti, meniti'

Vezavnostne možnosti pomena (a) 'misliti, meniti' s časovno opredelitvijo

\begin{tabular}{|c|c|c|c|}
\hline & misliti & mneti & meniti \\
\hline Snom - VF & 16.-20. stoletje & & \\
\hline Snom - VF - Sak & 16.-20. stoletje & & 16. -20 . stoletje \\
\hline Snom - VF - naSak & 16.-20. stoletje & & \\
\hline Snom - VF - vSak & 19. stoletje & & \\
\hline Snom - VF - kSdat & $\begin{array}{l}\text { 10. stoletje, } \\
\text { 16. stoletje }\end{array}$ & & \\
\hline Snom - VF - oSlok & 20. stoletje & & \\
\hline Snom - VF - poSlok & 16.-19. stoletje & & \\
\hline Snom - VF - INF & 19. stoletje & & \\
\hline Snom - VF - SENT & 16.-20. stoletje & 16. stoletje & 16.-20. stoletje \\
\hline Snom - VF - PG & 16.-20. stoletje & & \\
\hline Snom - VF - Sak* - odSgen & 18.-19. stoletje & & 19. stoletje \\
\hline Snom - VF - Sak* - oSlok & 19.-20. stoletje & & 20. stoletje \\
\hline Snom - VF - Sak* - sSins & & & 16. stoletje \\
\hline Snom - VF - Sak - SENT & & 16. stoletje & 16.-19. stoletje \\
\hline Snom - VF - naSak - SENT & 16. stoletje & & \\
\hline Snom - VF - zaSak - SENT & & & 20. stoletje \\
\hline Snom - VF - odSgen - SENT & 16. -19. stoletje & & 16.-19. stoletje \\
\hline Snom - VF - oSlok - SENT & 20. stoletje & & 20. stoletje \\
\hline Snom - VF - ADV & 16.-20. stoletje & & 16.-20. stoletje \\
\hline
\end{tabular}

Legenda:

16.-20. stoletje stabilni (ali bolj stabilni) vezavnostni vzorci

19. stoletje nestabilni (ali manj stabilni) vezavnostni vzorci

Med stabilnimi (ali bolj stabilnimi) vezavnostnimi vzorci jih sedem izkazujeta glagola misliti in meniti: Snom - VF - Sak, Snom - VF - SENT in Snom - VF ADV ustrezajo pomenskemu vzorcu nosilec mišljenja - vsebina (16.-20. stoletje); vzorci Snom - VF - odSgen // oSlok - Sak* in Snom - VF - odSgen // oSlok - SENT (v shemi sta desni določili zamenjani) pa pomenskemu vzorcu nosilec mišljenja - razmerni vsebinski udeleženec - vsebina.

Zadnji štirje vzorci si zaslužijo posebno opombo zaradi razmerja med določiloma odSgen in oSlok. Pri določilu v vlogi razmernega vsebinskega udeleženca 
v 19. stoletju nastopi zamenjava: odSgen zamenja oSlok (oSlok se v udeleženski vlogi pred drugo polovico 19. stoletja ne pojavlja).

Ostali stabilni vzorci zaznamujejo posamezne glagole: glagol misliti zaznamujejo Snom - VF (nosilec mišljenjskega procesa - proces), Snom - VF - naSak in Snom - VF - PG (nosilec mišljenja - vsebina); samo glagol meniti zaznamuje Snom - VF - Sak - SENT (nosilec mišljenja - prizadeto - vsebina). Vsi se pojavljajo v 16.-20. stoletju, le Snom - VF - Sak - SENT v 16.-19. stoletju.

Nestabilni (ali manj stabilni) vzorci zaznamujejo posamezne glagole; izjema so tisti, ki so pri drugem glagolu stabilni (kar dodatno potrjuje vezavnostno možnost; gl. shemo).

V pomenu 'misliti, meniti' prevladuje misliti, konkurira mu meniti, medtem ko ima mneti med glagoli marginalno vlogo (samo 16. stoletje). Predvsem glagol meniti (tudi mneti) izkazuje pomensko možnost 'imeti za', ki se kaže v vezavnostni možnosti Snom - VF - Sak - SENT; slednja se pričakovano ne pojavlja pri glagolu misliti (pomena 'imeti za' ne izkazuje).

Prevladujoča vezavnostna vzorca sta gotovo Snom - VF - Sak in Snom VF - SENT, dobro zastopani pa so tudi vzorci, ki ustrezajo pomenskemu vzorcu nosilec mišljenja - razmerni vsebinski udeleženec - vsebina (konkretneje zgoraj).

\subsubsection{Pomen (b) 'nameravati'}

Pomen 'nameravati' izkazujeta glagola misliti (2) in meniti (2). Pri obeh glagolih je pomen potrjen za obdobje od 16. do 21. stoletja.

(A) Vezavnostne možnosti pomena (b) 'nameravati'

Vezavnostne možnosti pomena (b) 'nameravati' s časovno opredelitvijo

\begin{tabular}{|l|c|c|}
\hline & misliti & meniti \\
\hline Snom - VF - naSak & 20. stoletje & \\
\hline Snom - VF - INF & $\mathbf{1 6 . - 2 0 . \text { stoletje }}$ & 16.-20. stoletje \\
\hline Snom - VF - SENT & 20. stoletje & \\
\hline
\end{tabular}

Legenda:

16.-20. stoletje stabilni (ali bolj stabilni) vezavnostni vzorci 20. stoletje nestabilni (ali manj stabilni) vezavnostni vzorci

Stabilen vezavnostni vzorec je zgolj Snom - VF - INF, ki ga izkazujeta oba glagola v obdobju od 16. do 20. stoletja (ustreza pomenskemu vzorcu nosilec namere - vsebina).

Nestabilna vzorca sta Snom - VF - naSak in Snom - VF - SENT (20. stoletje) in zaznamujeta samo glagol misliti (pomenski vzorec nosilec namere - vsebina).

$\mathrm{V}$ pomenu 'nameravati' prevladuje misliti, medtem ko je meniti nekoliko redkejši.

Prevladujoč vezavnostni vzorec v pomenu je Snom - VF - INF, medtem ko sta Snom - VF - naSak, Snom - VF - SENT redka; izpričana sta z osamljenima 
- zgledoma iz 20. stoletja, kažeta pa na nevtraliziran pomen namere. Sklepam, da je [स] INF tipično določilo za izražanje vsebinsko-namernega udeleženca.

\section{- 3.2.3 Drugi pomeni}

Pomen (c) izkazuje glagol misliti, pomen (č) pa zgolj meniti, zato primerjalna analiza ni mogoča. Za misliti (c) 'misliti, snovati v škodo/korist' gl. razdelek 2.1.3, za meniti (̌̌) 'reči, dejati' pa razdelek 2.3.3.

\section{$4 \quad$ Sklep}

Namena vezljivostne analize mišljenjskih glagolov misliti, mneti in meniti sta bila dva: (1) prikazati večplastnost vezljivostnih zmožnosti glagolov in razmerij med njimi v zgodovini slovenskega jezika; (2) dokazati, da se s spreminjanjem pomena glagolov spreminjata tudi njihova vezljivost in vezava.

Analizirani glagoli mišljenja so se izkazali za leksikalno zapleteno skupino glagolov. Glagola misliti in meniti sta večpomenska, pri čemer je lahko posamezen pomen (gradivsko) izkazan v celotni zgodovinski dobi jezika (npr. 'misliti, razmišljati' ob misliti) ali samo v določenem časovnem intervalu (npr. 'misliti, snovati v škodo/korist' pri misliti v 16.-19. stoletju, 'reči, dejati' ob meniti v 20. stoletju). Glagoli pomensko niso popolnoma prekrivni - ob skupnih (npr. 'misliti, meniti') izkazujejo tudi specifične pomene (npr. 'misliti, snovati v škodo/korist' ob misliti, 'reči, dejati' ob meniti). Med njimi se vzpostavljajo konkurenčna razmerja, ki so povzročila celo izgubo glagola mneti 'meniti' - v 16. stoletju se je namreč konkurenčno razmerje med mneti in meniti razrešilo v korist slednjega (prim. Merše 1995).

Potrdila se je domneva, da se s spreminjanjem pomena glagolov spreminjata njihova vezljivost (pomenska usmerjenost) in vezava. Znotraj pomenov se torej oblikujejo specifični pomenski vzorci, ki jim ustreza načeloma več vezavnostnih vzorcev. Tako npr. misliti v pomenu 'misliti, snovati v škodo/korist' oblikuje pomenski vzorec nosilec mišljenja - vsebina - prejemnik, ki mu ustrezajo vezavnostni vzorci Snom - VF - Sak* - Sdat // zoperSak // čezSak; meniti pa v pomenu v pomenu 'meniti, misliti, imeti za' kaže celo na štiri pomenske vzorce: (1) pomenskemu vzorcu nosilec mišljenja - vsebina ustrezajo vezavnostni vzorci Snom - VF - Sak, Snom - VF - SENT in Snom - VF - ADV; (2) pomenskemu vzorcu nosilec mišljenja - prizadeto - vsebina ustreza vezavnostni vzorec Snom - VF - Sak - SENT; (3) pomenskemu vzorcu nosilec mišljenja - razmerni vsebinski udeleženec - vsebina ustrezajo vezavnostni vzorci Snom - VF - odSgen - Sak* // SENT, Snom - VF - oSlok - Sak* // SENT in Snom - VF - zaSak - SENT; (4) pomenskemu vzorcu nosilec mišljenja - vsebina - razmerni udeleženec (prim. misliti - kaj, kako - s čim) pa vezavnostni vzorec Snom - VF - Sak* - sSins.

Vezljivostna analiza je pokazala, da je stabilnost posameznih vezljivostnih (pomenskih in vezavnostnih) razmerij pri glagolih mišljenja različna. Najbolj sta- 
bilen je pomenski vzorec nosilec mišljenja - vsebina, ki mu med vezavnostnimi ustreza Snom - VF - SENT; določilo SENT torej najbolj stabilno zaznamuje kompleksno vsebino mišljenjske dejavnosti. Pogosto je tudi nepropozicijsko določilo Sak, vendar pa kaže (tudi v časovni perspektivi) na tendenco k pomenski praznitvi (pomensko ekstenzivne prvine na mestu določila; leksikalna zapolnitev predložnosklonskih določil je bogatejša, prim. naSak, oSlok). Pomen 'nameravati' (predvsem ob misliti, nekoliko manj ob meniti) kaže na pomenski vzorec nosilec namere - vsebina, ki mu ustreza tipičen in zgodovinsko stabilen vezavnostni vzorec Snom - VF - INF (določilo INF je torej tipično v vlogi vsebine namere).

Kompleksnejši vzorci so manj ustaljeni od zgornjih. Pogostejši so predvsem vezavnostni vzorci Snom - VF - odSgen // oSlok - Sak* in Snom - VF - odSgen // oSlok - SENT, ki ustrezajo pomenskemu vzorcu nosilec mišljenja - razmerni vsebinski udeleženec - vsebina (ob misliti, meniti 'misliti, meniti'), redkejši pa je Snom - VF - Sak - SENT (pomenski vzorec nosilec mišljenja - prizadeto - vsebina) ob meniti (16.-19. stoletje).

Znotraj pomenskih razmerij se oblikuje načeloma več vezavnostnih vzorcev, med njimi (predvsem med posameznimi določilnimi možnostmi) pa se lahko vzpostavijo konkurenčna razmerja. Ob npr. misliti 'misliti, razmišljati' je prevladujoče desno določilo naSak (16.-20. stoletje), v posameznih obdobjih pa so mu konkurirala kSdat (10. stoletje, 16. stoletje), poSlok (16.-19. stoletje), vSak (19. stoletje), oSlok (20. stoletje). Med nekaterimi določili se lahko znotraj pomenskega razmerja pokažejo izrazitejše pomenske razlike. Ob misliti 'misliti, snovati v škodo/korist', ki so mu ustrezali vezavnostni vzorci Snom - VF - Sak* - Sdat // zoperSak // čezSak, so se v vlogi prejemnika pojavljala določila Sdat, zoperSak in čezSak. Medtem ko Sdat kaže na nevtralen prejemniški pomen, pa določili zoperSak, čezSak zaznamuje očitnejši protivnostni pomenski odtenek; ${ }^{40}$ pri zoperSak in čezSak pa je treba opozoriti na morebitno tujejezično motivacijo določil (kalk po nem. vzoru, prim. zoper - wider, čez - über). Zanimiva je tudi uveljavitev določila oSlok v škodo odSgen na mestu razmernega vsebinskega udeleženca, ki je zaznamovala slovenski knj. jezik v 19. stoletju; sprememba je bila najbrž rezultat vzpostavitve norme, ki kaže na odstranjevanje tujejezičnih oz. neslovanskih prvin iz knj. jezika (za hrv. jezik prim. Hudeček 2003).

Ob glagolih mišljenja je bila izpostavljena tudi vezljivostna vloga prislovnega določila ADV (tudi Sak*) kot »nadomestnega« določila, ki ima večinoma enako vlogo kot pomensko izpraznjeno določilo Sak; ADV oz. Sak* lahko pomensko variira ( $\mathrm{tj}$. je bolj ali manj povedno) glede na vezljivostne značilnosti glagola in leksikalno zapolnitev.

40 Samo ko se v vlogi prejemnika dejanja pojavlja določilo Sdat, je vsebina dejanja (Sak*) lahko tudi pozitivna. 


\section{Krajšave (oblike določil)}

Snom $=$ samostalnik $\mathrm{v}$ imenovalniku $(\mathbf{g e n}=$ rodilnik; dat $=$ dajalnik; $\mathbf{a k}=$ tožilnik; lok = mestnik; ins $=$ orodnik); odSgen $=$ predložnosklonska oblika samostalnika s predložnim morfemom od in rodilniško obliko samostalnika (prim. naSak, poSlok itn.); $\mathbf{S E N T}=$ odvisnik; $\mathbf{P G}=$ premi govor; $\mathbf{I N F}=$ nedoločnik; $\mathbf{A D V}=$ prislov

\section{Viri}

BS = France Bernik idr. (ur.), Brižinski spomeniki = Monumenta Frisingensia, Ljubljana: Založba ZRC, ZRC SAZU, ${ }^{3} 2004$.

DB = Jurij Dalmatin, BIBLIA, TV IE, VSE SVETV PISMV, STARIGA inu Noviga Teftamenta, Wittenberg, 1584, v: A. Metelko (ur.), Biblia Slovenica (CDROM), Ljubljana: Svetopisemska družba Slovenije, 2004.

Jap = Jurij Japelj idr., SVETU PISMU STARIGA INU NOVIGA TESTAMENTA, Ljubljana, 1784-1802, v: A. Metelko (ur.), Biblia Slovenica (CD-ROM), Ljubljana: Svetopisemska družba Slovenije, 2004.

Mikhailov 1998 = Nikolai Mikhailov, Frühslowenische Sprachdenkmäler: die handschriftliche Periode der slowenischen Sprache (XIV. Jh. bis 1550), Amsterdam - Atlanta (GA): Rodopi, 1998.

KB = Sebastijan Krelj, Otrozhia Biblia, Ljubljana: Mladinska knjiga, 1987 [ $\left.{ }^{1} 1566\right]$. Preš. = Peter Scherber, Slovar Prě̌ernovega pesniškega jezika, Maribor: Obzorja, 1977. Plet. = Maks Pleteršnik, Slovensko-nemški slovar I-II (transliterirana izdaja, ur. M. Furlan), Ljubljana: ZRC SAZU, 2006 ['1894-1895].

SJJSv = Marko Snoj, Slovar jezika Janeza Svetokriškega 1-2, Ljubljana: SAZU, 2006.

SSKJ = Slovar slovenskega knjižnega jezika 1-5, Ljubljana: SAZU oz. ZRC SAZU (izd.) - DZS (zal.), 1970-1991.

TA = Primož Trubar, Abecedarium, 1550, v: I. Grdina - F. Kranjc-Vrečko (ur.), Zbrana dela Primoža Trubarja I, Ljubljana: Rokus, 2002, 281-308.

$\mathrm{TAr}=$ Primož Trubar, Articuli oli deili te prave, stare vere kersčanske, 1562, v: I. Grdina - J. Vinkler (ur.), Zbrana dela Primoža Trubarja III, Ljubljana: Rokus, 2005, 5-224.

TC 1550 = Primož Trubar, Catechismus, 1550. V: I. Grdina - F. Kranjc-Vrečko (ur.), Zbrana dela Primoža Trubarja I, Ljubljana: Rokus, 2002, 19-278.

TC $1574=$ Primož Trubar, Ta celi catehismus, eni psalmi inu tih vegših godii stare inu nove kersčanske peisni, 1574, v: I. Grdina - J. Vinkler (ur.), Zbrana dela Primoža Trubarja IV, Ljubljana: Rokus, 2006, 271-454.

TO = Primož Trubar, Cerkovna ordninga, 1564, v: I. Grdina - J. Vinkler (ur.), Zbrana dela Primoža Trubarja III, Ljubljana: Rokus, 2005, 227-578.

VSSG = Andreja Žele, Vezljivostni slovar slovenskih glagolov, Ljubljana: Založba ZRC, ZRC SAZU, 2008 (Slovarji).

$\mathrm{W}=$ Anton A. Wolf (pobudnik), Sveto pismo stare in nove zaveze, 1856-1859, v: A. Metelko (ur.), Biblia Slovenica (CD-ROM), Ljubljana: Svetopisemska družba Slovenije, 2004. 


\section{Literatura}

Ágel 2000 = Vilmos Ágel, Valenztheorie, Tübingen: Gunter Narr Verlag, 2000.

Dogramadžieva 1989 = Ekaterina Dogramadžieva, Съюзните средства във фрайзингските паметници, Obdobje srednjega veka v slovenskem jeziku, književnosti in kulturi, Ljubljana: Filozofska fakulteta, 1989 (Obdobja 10), 63-68.

Dular 1982 = Janez Dular, Priglagolska vezava v slovenskem knjižnem jeziku (20. stoletja): doktorska disertacija, Ljubljana, 1982. Tipkopis.

ESJS = Eva Havlová idr. (ur.), Etymologický slovník jazyka staroslověnského 1-13[izhaja v zvezkih], Praha: Academia, 1989-2006-.

ESSJ = Oleg N. Trubačev idr. (ur.), Этимологический словарь славянских языков: праславянский лексический фонд 1-32-, Москва: Наука, 1974-2005-.

Hudeček 2003 = Lana Hudeček, Dopune glagolima govorenja, mišljenja i srodnih značenja u hrvatskome književnom jeziku od 17. do polovice 19. stoljeća strani sintaktički utjecaji, Rasprave Instituta za hrvatski jezik i jezikoslovlje 29 (2003), 103-129.

Karolak 1984 = Stanisław Karolak, Składnia wyrażeń predykatywnych, Gramatyka współczesnego języka polskiego: składnia, ur. Z. Topolińska, Warszawa: PWN, 1984, 11-211.

Kolarič 1968 = Rudolf Kolarič, Sprachliche Analyse, v: Freisinger Denkmäler = Brižinski spomeniki = Monumenta Frisingensia, München: Dr. Dr. Rudolf Trofenik, 1968 (Geschichte, Kultur und Geisteswelt der Slowenen 2), 18120.

Kopečný 1973 = František Kopečný, Etymologický slovnik slovanských jazyků I, Praha: Academia, 1973.

Merše 1995 = Majda Merše, Vid in vrstnost glagola v slovenskem knjižnem jeziku 16. stoletja, Ljubljana: SAZU, 1995 (Dela razreda za filološke in literarne vede 44).

Merše 2003 = Majda Merše, Glagolski kalki v zgodovini slovenskega knjižnega jezika (prevzemanje, raba in primerjava s stanjem v slovanskih jezikih), Slavistična revija 51 (2003), posebna številka, 81-103.

Orel 1993 = Irena Orel-Pogačnik, Predložni sistem v razvoju slovenskega knjižnega jezika od 16. do 19. stoletja: doktorska disertacija, Ljubljana, 1993. (Tipkopis.)

Orešnik 1992 = Janez Orešnik, Udeleženske vloge v slovenščini, Ljubljana, SAZU, 1992 (Dela razreda za filološke in literarne vede 37).

Paternu idr. 2004 = Boris Paternu idr., Prevod v sodobno slovenščino, v: Brižinski spomeniki = Monumenta Frisingensia, Ljubljana: Založba ZRC, ZRC SAZU, ${ }^{3} 2004,83-99$.

Pogačnik 1968 = Jože Pogačnik, Übersetzung ins Slowenische, v: Freisinger Denkmäler $=$ Brižinski spomeniki $=$ Monumenta Frisingensia, München: Dr. Dr. Rudolf Trofenik, 1968 (Geschichte, Kultur und Geisteswelt der Slowenen 2), 216-218. 
Pogorelec 1968 = Breda Pogorelec, Razvoj prostega stavka v slovenskem knjižnem jeziku (Vloga dativa v stavku), Jezik in slovstvo 13 (1968), št. 5, 145-150.

SČ 1998 = Miroslav Grepl - Petr Karlík, Skladba češtiny, Olomouc: Votobia, 1998. SJS = Josef Kurz - Zoe Hauptová (ur.), Slovník jazyka staroslověnského, Praha: Academia, 1966-1997.

Snoj 2003 = Marko Snoj, Slovenski etimološki slovar, Ljubljana: Modrijan, ${ }^{2} 2003$. SPP = Nad'a Svozilová idr. (ur.), Slovesa pro praxi, Praha: Academia, 1997.

Večerka 1993 = Radoslav Večerka, Altkirchenslavische (altbulgarische) Syntax II: Die innere Satzstruktur, Freiburg i. Br.: Weiher, 1993.

Vidovič-Muha 1984 = Ada Vidovič-Muha, Struktura glagolskih tvorjenk v Trubarjevi Cerkovni ordningi, Slavistična revija 32 (1984), št. 3, 245-256.

Vidovič-Muha 1988 = Ada Vidovič-Muha, Slovensko skladenjsko besedotvorje ob primerih zloženk, Ljubljana: Znanstveni inštitut Filozofske fakultete - Partizanska knjiga, 1988.

Vidovič Muha 2000 = Ada Vidovič Muha, Slovensko leksikalno pomenoslovje: govorica slovarja, Ljubljana: Znanstveni inštitut Filozofske fakultete, 2000.

VV 1987 = František Daneš idr., Větné vzorce v češtině, Praha, Academia, 1987.

Žele 2001 = Andreja Žele, Vezljivost $v$ slovenskem jeziku (s poudarkom na glagolu), Ljubljana: Založba ZRC, ZRC SAZU, 2001 (Linguistica et philologica 4).

Žele 2003 = Andreja Žele, Glagolska vezljivost: iz teorije v slovar, Ljubljana: Založba ZRC, ZRC SAZU, 2003 (Linguistica et philologica 8).

Žele 2007 = Andreja Žele, Povedkova lastnostna prislovna dopolnila, Slavistična revija 55 (2007), št. 1-2, 369-387.

\section{The valency of three verbs of thinking in the history of standard Slovenian (with an emphasis on government)}

\section{Summary}

This article presents findings on the valency of the verbs of thinking (verba sentiendi) misliti 'to think', mneti 'to believe', and meniti 'to believe' in the history of standard Slovenian. These verbs form a lexically complex group: misliti and meniti are polysemantic (they have both shared and different meanings), and the competition between mneti and meniti was resolved in the sixteenth century in favor of the latter.

Changes in the meaning of verbs correspond to changes in their valency and government. Within these meanings, specific semantic patterns are shaped, to which multiple government patterns generally belong. For verbs of thinking, the most stable semantic pattern is carrier of thought - content, which corresponds to $\mathbf{S}_{\text {nom }}-\mathbf{V F}-\mathbf{S E N T}$ in government (somewhat less stable is the pattern with a non-propositional semantically extensive right complement $\mathbf{S}_{\text {acc }}$ ); more complex semantic and government patterns are rarer. The meaning 'to intend' (for misliti, meniti) with the semantic pattern carrier of intention - content corresponds to the historically typical government pattern $S_{\text {nom }}-\mathbf{V F}-\mathbf{I N F}$. 
Competitive relationships may arise among government patterns (among right complements). For example, alongside the verb misliti 'to think, consider' the complement naS $\mathbf{S}_{\text {acc }}$ predominates (16th-20th centuries), competing in certain periods with $\mathbf{k S}_{\text {dat }}$ (10th century, 16th century), $\mathbf{p o S}_{\text {loc }}$ (16th-19th century), vi $\mathbf{S}_{\text {acc }}$ (19th century), and $\mathbf{o S}$ loc $(20$ th century). Complements can be marked by semantic differences; compare the neutral complement $\mathbf{S}_{\text {dat }}$ and the more explicit adversative zoperS $_{\text {acc }}$, čezS $\mathbf{S}_{\text {acc }}$ in the role of recipient for misliti 'to think, plan to detriment/ benefit'. In the nineteenth century, in place of the complement $\mathbf{o d} \mathbf{S}_{\text {gen }}, \mathbf{o S} \mathbf{S}_{\text {loc }}$ became established in the role of relational content participant, which points to the removal of foreign or non-Slavic elements from the standard language. Some complements point to a possible foreign-language motivation (following a German pattern); compare zoper - wider 'against', čez - über 'about'. The analysis also draws attention to the valency role of the adverbial complement ADV (also $\mathbf{S}_{\text {acc }}$ *) as a "substitute" complement that largely corresponds to the semantically bleached complement $\mathbf{S}_{\text {acc }}$. 